\title{
Anti-PMSG antibody levels in sheep subjected annually to oestrus synchronisation
}

\author{
L Bodin $^{1 *}$, PV Drion ${ }^{2}$, B Remy ${ }^{2}$, G Brice $^{3}$, \\ Y Cognié ${ }^{4}$, JF Beckers ${ }^{2}$ \\ 'SAGA, Inra, 31326 Castanet-Tolosan, France; \\ ${ }^{2}$ Physiologie de la Reproduction, Fac Méd Vét, Université de Liège, Sart-Tilman, Belgium; \\ ${ }^{3}$ Institut de l'élevage, 31326 Castanet-Tolosan; \\ ${ }^{4}$ Station PRMD, Inra, 37380 Nouzilly, France
}

(Received 27 February 1997; accepted 11 November 1997)

Summary - Estimation of the long-term consequences on reproduction performance of the oestrus synchronisation treatments that are annually applied to ewes was carried out on nine officially controlled dairy flocks in the Roquefort region of France. A hormonal treatment combining the insertion of a vaginal fluoro-gestone acetate (FGA) sponge for 14 days and the injection of about 500 IU of pregnant mare serum gonadotropin (PMSG) at withdrawal was applied to the ewes in seven of the nine flocks. The ewes in the two other flocks were used as controls. Blood samples were taken from each female just before the treatment (to test for the presence of residual antibodies) and 20 days after the PMSG injection. Anti-PMSG antibody binding rates were calculated for each blood sample. The residual binding rate increased with age and induce negative effects on the following years reproduction performances, ie, they increased the probability that the ewes would not become pregnant.

\section{sheep / repeated treatments / gonadotropins / refractoriness / antibody}

Résumé - Anticorps anti-PMSG chez la brebis soumise à un traitement annuel de synchronisation des chaleurs. Les conséquences des traitements annuels de synchronisation des œestrus sur les performances de reproduction des brebis ont été étudiées dans neuf troupeaux Lacaune de l'Aveyron (France) adhérant au contrôle laitier officiel. Un traitement hormonal, associant la pose d'une éponge vaginale imprégnée de fluorogestone acétate (FGA) pendant $14 \mathrm{j}$ suivi de l'injection de PMSG ( 500 UI) a été appliqué sur les brebis de sept troupeaux, les brebis des deux autres élevages, mises en lutte sur œstrus naturel ont servi de témoins. Des échantillons sanguins ont été prélevés juste avant l'injection de PMSG (pour tester la présence d'anticorps résiduels) et $20 \mathrm{j}$ après l'injection de PMSG. Le taux de liaison des anticorps anti-PMSG a été estimé par dosage

\footnotetext{
* Correspondence and reprints
}

Tel: (33) 0561285185 ; fax: (33) 0561285353 
radio-immunologique pour chaque échantillon. Les taux de liaison résiduels augmentent avec l'âge des brebis et ont des effets négatifs sur les performances de reproduction ultérieures : les taux élevés sont associés à de faible fertilité après insémination.

ovin / traitement hormonal / gonadotrophine / anticorps / PMSG

\section{INTRODUCTION}

Gonadotropin treatments are used for oestrus induction to synchronise the cycle of large numbers of females or to induce superovulation. They have been used on cattle for more than 50 years (Staigmiller et al, 1992) and at the present time they are also widely used for horses, sheep and goats. For these species, oestrus induction treatment allows ewe fertilisation during the non-breeding season but is also an essential requirement for artificial insemination.

Several studies in cattle sheep and goats have shown that for large scale superovulation, porcine pituitary extract (Willet et al, 1953; Remy et al, 1991; Staigmiller et al, 1992) or a crude extract of PMSG (Willet et al, 1953; Gherardi and Martin, 1978; Christie et al, 1979; Armstrong et al, 1983; Bavister et al, 1986; Baril et al, 1992a, b; Beckers et al, 1995) can be used as a source of FSH activity. However, for oestrus synchronisation even though pFSH can be used, PMSG is preferable because it is administred in a single dose.

Studies on cattle (Willet et al, 1953; Christie et al, 1979; Alwan et al, 1988), and goats (Maurer et al, 1968; Gherardi and Martin, 1978; Armstrong et al, 1983; Remy et al, 1991; Baril et al, 1992b; Beckers et al, 1995), have described an increasing level of refractoriness in animals receiving successive treatments. Some of these authors have demonstrated the presence of antigonadotropin antibodies in the refractory animals (Pignon et al, 1960; Jainudeen et al, 1966; Maurer et al, 1968; Alwan et al, 1988; Bavister et al, 1986; Remy et al, 1991; Baril et al, 1992b). Moreover, Beckers et al (1995) showed that goats treated with eCG, transmitted anti-eCG antibodies in their colostrum.

In dairy sheep flocks in the south of France, where oestrus synchronisation is performed each year at the beginning of the breeding season, a decreased fertility was observed in the treated ewes. It was noted that this decrease was correlated to the age of the animals and, therefore, to the number of treatments they have received. Because an immune reaction to exogenous gonadotropins has been shown to generate refractoriness to subsequent fertility treatments in cattle and goats, we decided to perform a large scale study of this phenomenon in sheep.

\section{MATERIAL AND METHODS}

\section{Selection of flocks}

Nine officially controlled dairy flocks belonging to two breeding associations in the Roquefort region were followed for 1 year, beginning at the start of the breeding season of 1992. Of these nine flocks, seven had annual oestrus synchronisation applied to $80-90 \%$ of the females, in order to facilitate management and genetic requirements. The two other farms (one for each selection programme) were used as control flocks because this oestrus synchronisation treatment (FGA + PMSG) was never used. Moreover, these breeders never introduced new ewes from other flocks to their flocks.

For the nine selected flocks, the flock size, age distribution and management were representative of local practices. 


\section{Breeding}

\section{Treated flocks}

For each flock, a group of lactating females $(\sim 100)$ received, between 18 June 1992 and 19 July 1992, a synchronisation treatment [vaginal sponge of $40 \mathrm{mg}$ of FGA (Intervet, Angers, France)].

Sponges were removed after 14 days and 500-550 IU of PMSG were then injected im (table I). The females were inseminated $55 \mathrm{~h}$ after sponge withdrawal, with approximately 400 milion spermatozoa placed near the cervix.

The above treatment was the same as that normally practised on sheep in the Roquefort region.

In 1992, two blood samples were taken from each ewe: one at vaginal sponge insertion and the other 20 days after the PMSG administration.

\section{Control flocks}

In these flocks, mating took place during the same period as for the treated flocks. A single blood sample was collected in 1992, just before the beginning of the mating period.

\section{Antibody detection in plasma samples}

The blood samples were collected in $5 \mathrm{~mL}$ evacuated heparinized tubes, centrifuged and the plasma was stored at $-15^{\circ} \mathrm{C}$ until assay. The blood samples obtained at sponge insertion and 20 days after PMSG injection were checked for the presence of anti-PMSG antibodies in the treated animals by radio immunoassay and the results were expressed as a percentage of radioactive PMSG binding.

A PMSG preparation provided by Intervet (Organon Oss, the Netherlands) was used for the radio immunoassay. The biological activity of the purified preparation was about 10000 IU per $\mathrm{mg}$ as determinated by the Steelman and Polhey (1953) bioassay.

Purified PMSG was radiolabelled using ${ }^{125}$ Iodine (NEN IMS-30) as per the enzymatic procedure of Thorell and Johanson (1971).

The labelled hormone was then purified by chromatography on a G-75 Pharmacia column $(0.9 \times 35 \mathrm{~cm})$ equilibrated in Tris- $\mathrm{HCl}$ buffer $0.01 \mathrm{M}$; pH 7.6 containing $0.1 \%$ bovine serum albumin (bSA).

Antibody levels were measured on sera diluted $1 / 10$. The procedure involved incubation of $100 \mu \mathrm{L}$ of diluted serum with $33.333 \mathrm{dpm}$ of ${ }^{125} \mathrm{I}$ PMSG for $16 \mathrm{~h}$ at $20^{\circ} \mathrm{C}$. The antibodies were then precipitated by adding donkey antiewe immunoglobulin for $1 \mathrm{~h}$ at $20^{\circ} \mathrm{C}$ and polyethylene glycol (4\%).

The tubes were then centrifuged at $2500 \mathrm{~g}$ for $20 \mathrm{~min}$, the supernatants discarded and radioactivity in the pellets counted.

Non-specific binding (NSB) of ${ }^{125}$ I PMSG was determined using plasma (in duplicate) obtained from ten ewes which had never been treated with exogenous gonadotropins.

Table I. Features of the seven 'treated' and two 'control' flocks.

\begin{tabular}{lccccc}
\hline Flock & $\begin{array}{c}\text { Number } \\
\text { of ewes }\end{array}$ & $\begin{array}{c}\text { Date of AI } \\
\text { or mating }\end{array}$ & $\begin{array}{c}\text { PMSG } \\
\text { dose }\end{array}$ & $\begin{array}{c}\text { Fertility } \\
\text { on IO }\end{array}$ & $\begin{array}{c}\text { Prolificacy } \\
\text { on IO }\end{array}$ \\
\hline 1 & 92 & $19-06$ & 500 & 65.2 & 191.6 \\
2 & 93 & $19-06$ & 500 & 73.1 & 165.0 \\
3 & 82 & $18-07$ & 500 & 61.7 & 160.0 \\
4 & 98 & $25-06$ & 550 & 62.4 & 160.3 \\
5 & 100 & $30-06$ & 540 & 56.4 & 181.1 \\
6 & 92 & $27-06$ & 530 & 48.2 & 147.5 \\
7 & 114 & $24-06$ & 530 & 63.3 & 191.9 \\
Control A & 98 & $10-07$ & - & - & - \\
Control B & 90 & $25-05$ & - & - & - \\
\hline
\end{tabular}

\footnotetext{
${ }^{\mathrm{a}} \mathrm{IO}$, Induced oestrus.
} 


\section{Statistical analysis}

The analysis of factors having a possible influence on the anti-PMSG antibody binding rates was performed by a variance analysis using the GLM procedure (SAS, 1989). Age, flock and interaction between these factors were considered as the fixed main effects. The logarithm of the binding rate at the beginning of treatment (residual binding rate) was added as a covariable to the rate obtained 20 days after PMSG administration. Correlations of individual binding rates before and after a new treatment were estimated for residual binding rates (corrected for significant effects) as well as for raw binding rates.

Four classes of residual binding rate $(<3 \%$; $3-6 \% ; 6-12 \% ;>12 \%)$ and four classes of binding rates after treatment $(<10 \% ; 10-20 \%$; $20-30 \%$; $>30 \%$ ) were defined in order to compare binding rate distribution between control and treated flocks. Comparisons of this distribution for pregnant and non-pregnant ewes as well as for ewes with different litter size $(1-2-3+)$ were also performed using the $\chi^{2}$ method.

The effects of the antibody levels on fertility and prolificacy were determinated using the Probit Procedure (SAS, 1989). This model considered the categorical trait (fertility: 0-1; prolificacy: $1-2-3+$ ) as a combination of a continuous underlying variable and a set of fixed thresholds which impose a discontinuity on its visible expression. The estimates of effects having an influence on the underlying variable (age, flock, covariable) and related threshold values are estimated by the 'maximum likelihood method'.

\section{RESULTS}

\section{Control flocks}

The PMSG binding rates detected in the plasma samples from the control flocks, where the ewes had never received hormonal treatment, were low $(\mu=0.69 ; \mathrm{SD}=$ 0.56 ), with $95 \%$ of the binding rates below $1.5 \%$.

Variance analysis showed a non-significant difference in binding rate between these two flocks and that the age effect was also not significant.

\section{Treated flocks}

\section{Antibody levels '20 days after injection'}

Figure 1 shows the binding rate distribution for anti-PMSG antibody 20 days after the

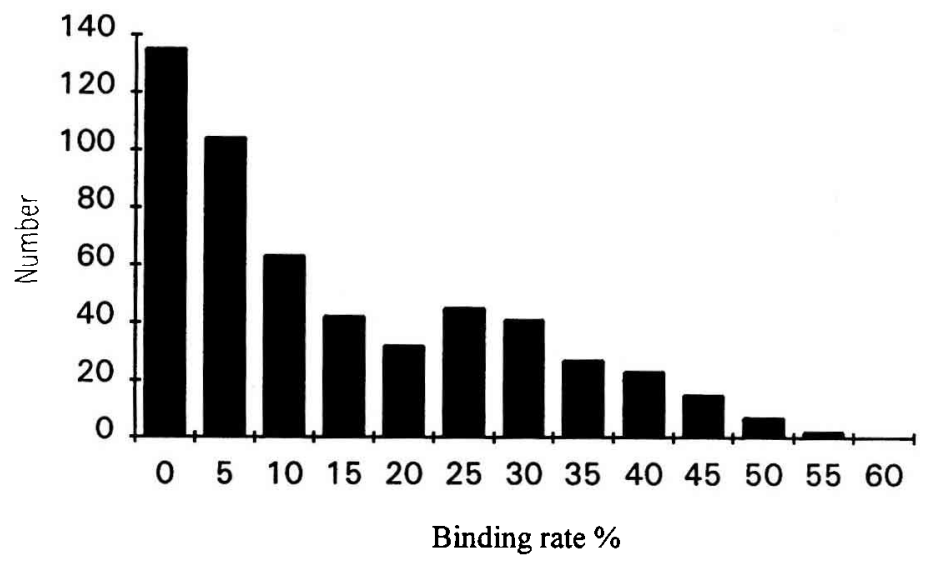

Fig 1. Distribution of anti-PMSG binding rates 20 days after PMSG injection. 


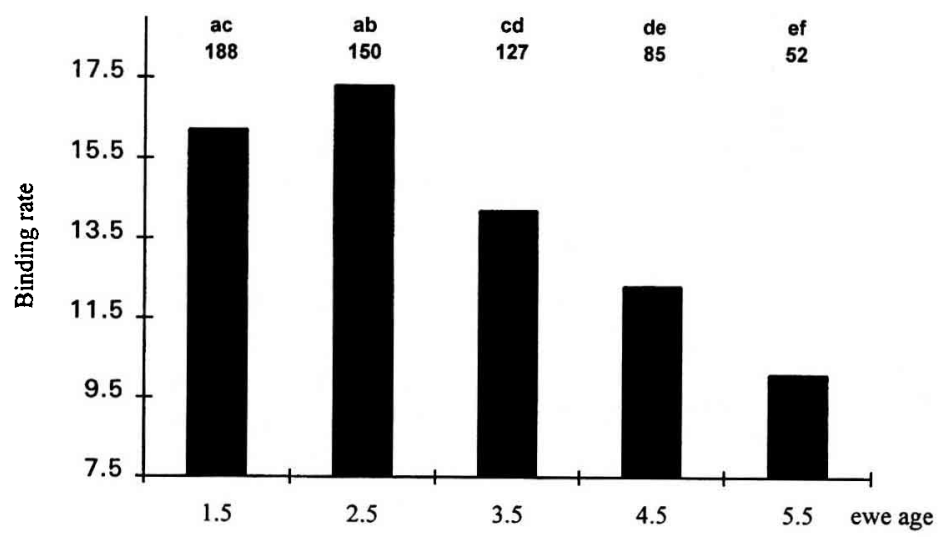

Fig 2. Changes in binding rates of anti-PMSG antibodies with ewe age, 20 days after PMSG injection (least square means with different subscripts are significantly different).

PMSG injection. This distribution was highly variable. The mean was $14.7 \% ; 81 \%$ of ewes showed binding rate values between 0 and $30 \%$; a few females $(5 \%)$ showed a binding rate higher than $40 \%$.

No significant relationship was observed between the average binding rate in each flock and the PMSG dose the ewes were given. No significant effect either for flock, or for sheep age was found by variance analysis. Only the (age $\times$ flock) interaction showed a significant effect $(P<0.01)$.

When the residual antibody level at the moment of the treatment was taken into consideration (the logarithm of residual binding rate was used as a covariable), the variance error was reduced by $26 \%$ and the age and covariable effects then became significant. When the ewes were older, the binding rate of anti-PMSG antibodies 20 days after the PMSG injection decreased (fig 2).

\section{Residual antibodies}

Figure 3 shows the distribution of the residual antibody binding rate at the beginning of a new treatment and the distribution of binding rate in control flocks. In the treated flocks, the mean binding rate was lower $(\mu=4.3 \%)$ than it had been 20 days after injection. Mode value was $1.25 \% ; 80 \%$ of values were lower than the mean and $14 \%$ of the sheep had a binding rate higher than $12 \%$. Table II shows the proportion of ewes of the two types of flocks in each class of binding rate and the $\chi^{2}$ probability.

Variance analysis showed that age had a highly significant effect on the binding rate of the anti-PMSG antibodies $(P<0.01)$, the

Table II. Distribution comparison of the residual antibody binding rate at the beginning of a new treatment and the distribution of binding rate in control flocks.

Binding rate class $<3 \% \quad 3-6 \% \quad 6-12 \%>12 \%$

$\begin{array}{lllll}\text { Control flocks (\%) } & 70.4 & 13.8 & 5.5 & 10.3\end{array}$

$\begin{array}{lllll}\text { Treated flocks (\%) } & 98.9 & 1.1 & 0.0 & 0.0\end{array}$

$\begin{array}{ll}\text { Prob } \chi^{2} & 0.0001\end{array}$ 


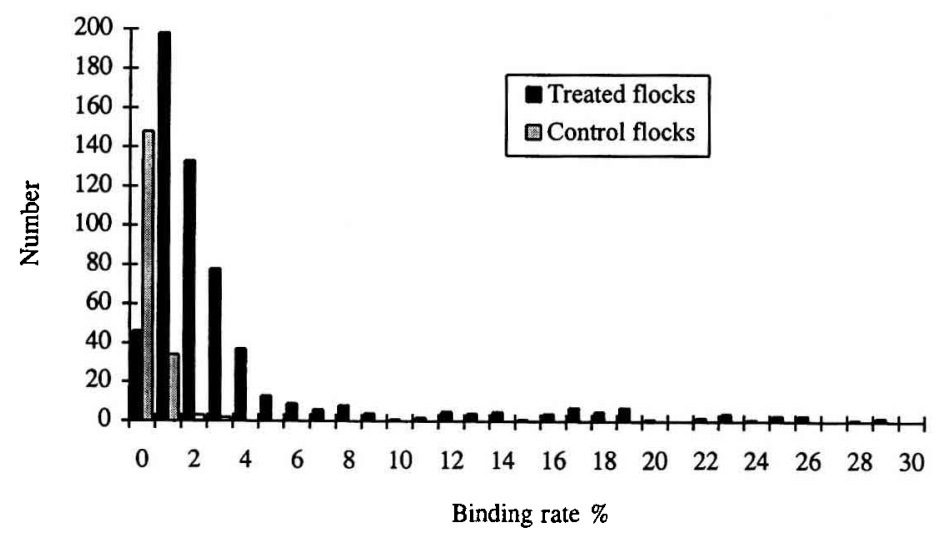

Fig 3. Distribution of anti-PMSG binding rate in control flocks and in treated flocks at the beginning of a new treatment (residual antibodies).

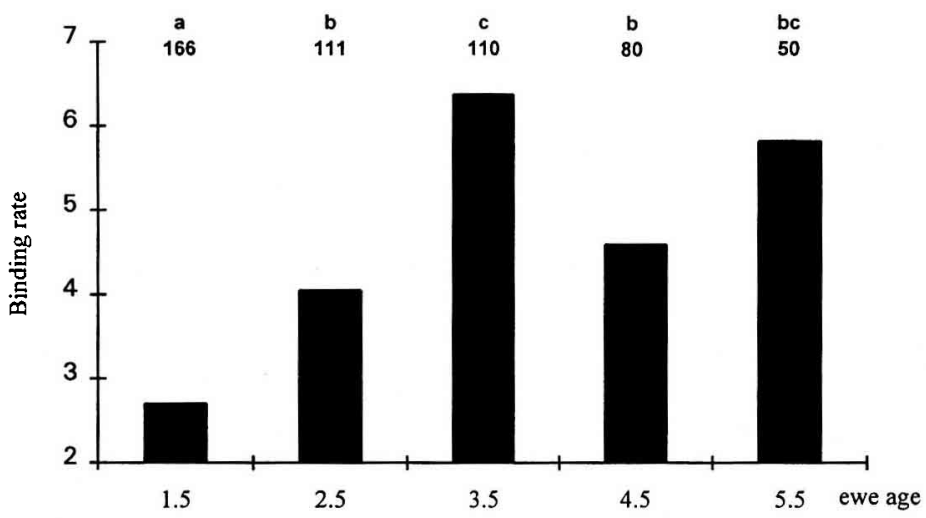

Fig 4. Changes in residual binding rates (residual anti-PMSG antibodies) with age (least square means with different subscripts are significantly different; and ewe number at each age).

binding rate increased with age of the ewes (fig 4).

\section{Relation between 'residual antibody' binding rate and 'after treatment' binding rate}

The correlation between the binding rate before and after a new treatment was sig- nificantly different from zero $(r=0.47$; $P<0.01)$ and was similar whether raw values were considered, or values that had been corrected for the significant effects of the variance analysis.

Since a few extreme values might have induced this correlation, the correlation was also calculated on a sample in which the very high binding rates were discarded (12\% of the values). Lower correlations $(r=0.33)$ 
Table III. Reproductive performances of ewes according to four and two classes of antibody binding rate.

\begin{tabular}{|c|c|c|c|c|c|c|}
\hline \multirow{2}{*}{$\begin{array}{l}\text { Binding } \\
\text { rate class } \\
(\%)\end{array}$} & \multirow{2}{*}{$\begin{array}{c}\text { Number of } \\
\text { treated } \\
\text { ewes }\end{array}$} & \multicolumn{2}{|c|}{ Fertility } & \multirow{2}{*}{$\begin{array}{c}\text { Number of } \\
\text { lambing } \\
\text { ewes }\end{array}$} & \multicolumn{2}{|c|}{ Prolificacy } \\
\hline & & four classes & two classes & & four classes & two classes \\
\hline$<3$ & 424 & 0.64 & & 272 & 1.76 & \\
\hline $3-6$ & 83 & 0.62 & 0.64 & 52 & 1.77 & 1.76 \\
\hline$>6-12$ & 33 & 0.54 & & 18 & 1.50 & \\
\hline$>12$ & 62 & 0.48 & 0.50 & 30 & 1.50 & 1.50 \\
\hline Prob $\chi^{2}$ & & 0.09 & 0.01 & & 0.17 & 0.04 \\
\hline
\end{tabular}

were obtained. The estimations on the raw or corrected values, however, remained similar and were always very significantly different from zero $(P<0.01)$.

\section{Relation between antibody binding rate and reproduction performances}

\section{Binding rates '20 days after injection'}

The immediate effects of the anti-PMSG antibodies on reproduction in progress were indirectly estimated by comparing the reproductive performances of ewes spread into four classes of antibody binding rates (<10\%; 10-20\%;20-30\%; >30\%). No significant difference in fertility or prolificacy was found between these four classes (respective probability $\chi^{2}=0.8$ and 0.9 ). When animals were spread into two groups, ie, those with a binding rate of greater or less than $20 \%$, no statistically significant differences in fertility or prolificacy were observed.

Analysis of fertility and prolificacy with a threshold model, taking into account the effects of age, flock and the logarithm of antibody binding rate as a covariable, showed that this covariable had no significant effect.

\section{Residual antibodies}

A comparison of reproductive performance according to four arbitrary classes of residual antibody binding rates $(<3 \% ; 3-6 \%$; $6-12 \% ;>12 \%$ ) showed that when the binding rate increased, the fertility significantly decreased $(P>9 \%)$.

In contrast, the decrease observed for prolificacy was not significant (table III). However, when animals were classed into two groups, females with a higher binding rate $(>6 \%)$ had a significantly lower prolificacy than the others.

The fertility analysis with a threshold model, taking into account the effects of age, flock and the logarithm of residual antibody binding rate as a covariable, showed that all these effects were significant although there was no clear trend of change of fertility with age. This model also showed that increasing the binding rate increased the probability that the ewes would not become pregnant $(P>0.01)$.

\section{DISCUSSION}

This study was the first large scale study reporting anti-PMSG antibody detection in sheep treated annually with low doses of 
PMSG and followed a preliminary study (Brice, 1991) performed on the same flocks of sheep.

Such antibodies had already been identified in treated sheep using an ELISA assay (Rainio, 1992) but this study concerned animals treated every 2 months with large doses of PMSG (1200-1800 IU). Anti-PMSG antibodies had previously been suspected in cattle (Willet et al, 1953) as in ewes (Hulet and Foote, 1969; Clarke, 1973; Gherardi and Martin, 1978) which had suddenly shown lower rates of embryo recovery. Several subsequent studies demonstrated these antibodies in goats (Baril et al, 1992a, b), cattle (Jainudeen et al, 1966) and rabbits (Canali et al, 1991).

As expected, in the control flocks where the ewes had never received PMSG injections, the detected binding rates were low (approximately 1-2\%) although five ewes among 187 presented binding rate slightly above the sensitivity of the assay which was calculated at $2 \%$. Whether this binding level was due to antibodies which cross react with PMSG or to technical reasons was not clear.

The PMSG doses injected for this study were chosen to stimulate an ovulation within a short time after the sponge removal rather than to induce a superovulation. These doses were low and, in order to eliminate a dose effect, the same number of units were injected irrespective of the weight of the animals. The high dispersion of binding rate distribution therefore revealed the very large variability in sheep responses to a single injection of PMSG. A similar dispersion of response was found in the study by Rainio (1992), who worked with much higher and variable doses of PMSG and did not find a relationship between the dose of PMSG and the induced antibody rate. It should be noted, however, that a few sheep showed an exceptionally high response (binding rate $\geq 40 \%$ ), a phenomenon which has already been described (Baril et al, 1992a, b).

\section{Binding rates 'twenty days after treatment'}

The steady decrease of antibody binding rates 20 days after treatment corresponding to increased ewe age (and therefore to the number of treatments) was unexpected. This could be explained by the selection programme which is applied to the flocks, and the automatic culling of females which do not become pregnant. But anti-PMSG antibodies change fertility only after artificial insemination and ewes can be fertilized upon returning to oestrus. Another hypothesis is that this decrease could be due to a reduction in the capacity of females to respond immunologically to the antigen.

The immediate response to the treatment is an increase in antibody level which seems to have no effects upon reproduction in progress. This antibody increase occurs too long after the PMSG injection to modify its effects on the pregnancy in progress, but it produces negative effects on subsequent reproduction.

\section{Binding rates \\ ' 1 year after treatment'}

The existence of anti-PMSG antibodies, though suspected for a long time, has only recently been demonstrated. Their negative effects on cattle, goats and sheep have been described for many years. For instance, these negative effects have been reported in goats, when the female receive two treatments during the same breeding-season (Baril et al, $1992 \mathrm{a}, \mathrm{b}$ ), and in ewes when the delay between injections is only 1 month (Rainio, 1992). Our results showed that reproduction is affected by 'residual antibodies' still present at the beginning of a new treatment. The presence of such residuals was due to the previous administration of PMSG 1 year before and probably reflected a very slow clearance rate for these antibodies. This binding rate gradually decreased over time, 
as in a prior study of goats (Baril et al, 1992b). As had been previously observed (Rainio, 1992), and also noted in our experiment, older ewes have higher residual binding rates. This may be explained, as it was for goats (Baril et al, 1992b), by an accumulation of antibodies due to successive treatments.

Finally, a strong positive correlation was found between residual binding rates and binding rates 20 days after treatment. This positive correlation was not induced by some sheep with very high binding rates, since the correlation stayed high even after disregarding the very high binding rates. Those high values (even when corrected for age and flock effects) very likely reflected high antibody levels which had not been cleared when the next treatment was applied. This supported our conclusion that the more marked the immunological reaction to one injection of PMSG, the lower the probability of a successful response to a subsequent treatment

In conclusion, this study clearly showed that an im PMSG injection at a dose recommended for oestrus synchronisation induced anti-PMSG antibody production, which in turn produced negative effects when the next treatment was applied. In the sample studied, $15 \%$ of females with residual antibody binding rates higher than $6 \%$ displayed a significantly lower fertility at the following artificial insemination. Due to the accumulation of residual antibodies remaining after successive treatments, it is recommended that the PMSG treatment of females remaining unpregnant is discontinued. However, these females remain suitable for natural reproduction.

\section{ACKNOWLEDGMENTS}

The authors wish to acknowledge the 'Groupe de physiologie de la reproduction' of the CNBL for their input and feedback on this project. Special thanks are given to EM Mc Namara and C Jardon as well as to the technicians and the breeders who participated in this study. The IRSIA (Institut pour l'Encouragement de la Recherche Scientifique dans l'Industrie et l'Agriculture, Brussels, Belgium) is also gratefully acknowledged for its financial help.

\section{REFERENCES}

Alwan SF, Boland MP, Goudon I (1988) Detection of antibodies following repeated superovulation in beef heifers. Proc 11th Int Cong on Anim Reprod and Artif Insem 2, 139-141

Armstrong DT, Pfitzner AP, Warnes GM, Seamark R (1983) Superovulation treatments and embryo transfer in Angora goats. J Reprod Fert 67, 403-410

Baril G, Remy B, Vallet JC, Beckers JF (1992a) Observations sur l'utilisation de traitements gonadotropes répétés chez la chèvre laitière. Ann Zootech 41, 291-296

Baril G, Remy B,Vallet JC, Beckers JF (1992b) Effect of repeated use of progestagen-PMSG treatment for estrus control in dairy goats out of breeding season. Reprod Dom Anim 27, 161-168

Bavister BD, Dees C, Schultz R (1986) Refractoriness of Rhesus monkeys to repeated ovarian stimulation by exogenous gonadotropins is caused by nonprecipiting antibodies. Am J Reprod Immunol Microbiol 11-16

Beckers JF, Remy B, Baril G, Figueiredo JR, Bureau F, Sulon J, Saumande J (1995) Anti-eCG antibodies are transmitted via the colostrum in goats. Theriogenology 43, 165

Brice G (1991) Recherches sur les causes de la baisse de fertilité des brebis agées observée parès synchronisation hormonale des chaleurs et insémination artificielle. Document ITOVIC

Canali C, Boiti C, Zamfiri D, Castellini C, Baltaglini M (1991) ATTI IW Congreso Nazionale ASPA 671678

Christie WB, Newcomb R, Rowson LEA (1979) Ovulation rate and egg recovery in cattle treated repeatedly with PMSG and prostaglandin. The Veterinary Record 31, 281-283

Clarke IJ (1973) Repeated gonadotrophic stimulation of ewes. NZ Soc Anim Prod 33, 204

Gherardi PG, Martin GB (1978) The effect of multiple injections of PMSG on the ovarian activity of Merino ewes. Proc Aust Soc Anim Prod 12, 160

Hulet CV, Foote WC (1969) Ovulatory response of the ewe to repeated injections of PMSG. J Anim Sci 29, 457-463 
Jainudeen HR, Hafez ESE, Gollmick PD, Moustafa LF (1966) Antigonadotropins in the serum of cows following repeated therapeutic pregnant mare serum injections. Am J Vet Res 27, 669-675

Maurer RR, Hunt WL, Foote RH (1968) Repeated superovulation following administration of exogenous gonadotropins in Dutch-belted rabbits. $J$ Reprod Fert 15, 93-102

Pignon H, Clegg MT, Cole HH (1960) The formation of antigonadotropin in sheep and its effects on the endocrines and reproductive system. Acta Endocrinol 35, 253-260

Rainio V (1992) Embryo Production in Finssheep, Academic Dissertation. University of Kuopio

Remy B, Baril G, Vallet JC, Dufour R, Chouvet C, Saumande J, Chuplin D, Beckers JF (1991) Are antibodies responsible for a decrease superovulatory response in goats which have been treated repeatedly with porcine follicle-stimulating hormone? Theriogenology 36, 389-399
SAS Institute Inc (1989) SAS/STAT User's Guide, Version 6, Fourth edition, Volume 2, SAS Institute Inc, Cary, NC

Staigmiller RB, Bellows RA, Anderson GB, Seidel G.E Jr, Foote WD, Menino AR Jr, Wright RW Jr (1992) Superovulation of cattle with equine pituitary extract and porcine FSH. Theriogenology 37, 10911099

Steelman SL, Pohley FM (1953) Assay of the follicle stimulating hormone based on the augmentation with human chorionic gonadotropin. "Assay on FSH" 53, 604-616

Thorell JI, Johansson BG (1971) Enzymatic iodination of polypeptides with 125 I to high specific activity. Biochem Biophys Acta 251, 363-369

Willet EL, Buckner PJ, McShan WH (1953) Refractorines of cows repeatedly superovulated with gonadotropins. J Dairy Sci 36, 1083-1087 